\section{CONTENTS VOL. 44 (1-5)}

February, 1968 1.

Editorial - Our new format

Page

Simulation Models in Forest Management and Harvesting, 7 by R. M. Newnham.

Reforestation in Ontario, by G. E. MacKinnon 14

Growing Tubed seedlings in the Kenora Forest District, 18 by $\mathrm{G}$. H. Kokocinski.

Changing Forestry Environment: The Full Forest, by $L$. A. deGrace

Changing Forestry Environment: Resources Management 24 in the Urban Golossus, by K. G. Higgs.

The Effects of Political Change: Competing Uses of Land, 26 by R. W. B. Thompson.

Effects of Technological Changes on Woods Operations, 28 by Ivar F. Fogh.

V-Gauge, by I. E. Bella

Institute Affairs

Section Affairs

$\begin{array}{cl}\text { Page } & \text { Forestry in Action } \\ 34 & \text { Letters } \\ 36 & \text { Reviews } \\ 40 & \text { Advertisers Index } \\ & \text { Current Publications } \\ 41 & \text { Membership }\end{array}$

32

44

45

Provincial Professional News

Outer Bark

2.

Editorial - Increasing use of forestry consultants

Relationships Between External Features and Trunk Rot in Living Yellow Birch, by André Lavallée and Marcel Lortie

Upwards from the Plateau, by G. H. Bayley

Upwards from the Plateau, A Consulting Forester's View, by E. S. Fellows.

Public Use of Forest Wildlife - Economic Aspects, by F. A. Walden.

Forest Management Statistics for Canada, by Peter J. Murphy

Computers and Forest Fire Detection by $P$. H. Kourtz

Development of Black Spruce Layers in Quebec and 25 Ontario, by W. Stanek

Application of Life-Table Analyses to Tree Seedlings in 29 Quetico Provincial Park, Ontario, by Joan M. Hett and Orie L. Loucks.

To-Morrow's Forester - What will he be like? by Vernon Knight

Forestry in Action

Institute Affairs

Section Affairs

Provincial Professional News

Membership

Outer Bark

$\begin{array}{clc}\text { Page } & & \text { Page } \\ 37 & \text { Letters } & 67 \\ 39 & \text { For the Sake of } & \\ 41 & \text { Argument } & 71 \\ 52 & \text { Reviews } & 73 \\ & \text { Current Publications } & 75 \\ 57 & \text { Obituaries } & 78 \\ 58 & \text { Adverisers Index } & \text { I.B.C. }\end{array}$

June, 1968

3.

Editorial - Request for controversial opinions

New Approaches to Forest Recreation Planning in Canada, 5 by C. S. Brown.

A Comparison of Photo and Ground Measurements of Canopy Density, by G. M. Bonnor.

Budworm Attacks: Regional Variation in Susceptibility based on Outbreak Histories, by J. R. Blais.

The Future of Recreation on Wildlands, by $R$. Yorke Edwards.

Chipper Headrigs for Processing Small logs, by P. M. Morley.

Management of Spruce Budworm Populations, by D. R. Macdonald.

Decay in Advanced Alpine Fir Regeneration, by R. B. Smith and H. M. Craig.

Growth of White Spruce Planted in the Turtle Mountains, 45 by I. E. Bella.

Institute Affairs

Forestry in Action

Section Affairs

Provincial Professional News

$\begin{array}{cl}\text { Page } & \\ 47 & \text { Letters } \\ 49 & \text { Outer Bark } \\ 50 & \text { Obituaries } \\ 55 & \text { Reviews } \\ & \text { Membership }\end{array}$

August, 1968

4.

Editorial - Exploding literature

Détermination de la qualité de l'érable à sucre d'après des signes apparents de carie, par André Lavallée.

A Method of Constructing Site-Index Curves from Stem 11 Analyses, by L. Heger.

An Evaluation of the McClure and Wheeler Optical 16 Calipers, by Wallace $\mathrm{C}$. Robbins and Harold E. Young.

Spring Planting with Jack Pine Transplants Recommended for Blueberry-Sweetfern Sites in Northern Ontario, by R. E. Mullin.

Conversion Surplus as a Measure of Value, by William A. Duerr and Sam Guttenberg.

Protein and Caloric Content of Lodgepole Pine Needles, 28 by D. A. Boag and J. W. Kiceniuk.

Influence of Manganese on Growth of Jack Pine and 32 Black Spruce Seedlings, by I. K. Morrison and K. A. Armson.

An Underplanting Experiment with White Pine and White Spruce Seedling and Transplant Stock, by B.S.P. Wang and K. W. Horton

Institute Affairs
Section Affairs
Letters
Outer Bark

$\begin{array}{cl}\text { Page } & \\ 52 & \text { Obituaries } \\ 56 & \text { Reviews } \\ 65 & \text { Current Publications } \\ 67 & \text { Advertisers Index } \\ & \text { Membership }\end{array}$

5.

Editorial - Forestry and rural poverty
An Outline of Professional and Non-Professional Forestry 5 Training in Norway, Sweden, West Germany and France, by Q. F. Hess.

Lateral Root Pruning - A Promising Nursery Practice, 12 by $S$. Eis.

Results of an Aerial Spraying Operation Against the 14 Swaine Jack Pine Sawfly, Neodiprion swainei Middleton, in Quebec utilizing the Insecticide Phosphamidon, by J. M. McLeod

The Rhizometer - A Device for Measuring Roots of 21 Tree Seedlings, by K. A. Armson and I. K. Morrison.

Interpolation Errors on Some Stem Profiles, by G. M. Bonner.

The Influence of Soil Moisture Deficits on Seedling 26 Growth of Three Coniferous Species, by C. Glerum and G. Pierpoint

Drought Conditions for Burning Ran Humus on Clear- 30 Cut Jack Pine Sites in Central Ontario, by $Z$. Chrosciewicz.

Areal Rainfall Variability and its Effect Upon Forest Fire Danger Rating, by M. S. Webb.

Canadian Theses in Forestry and Related Subject Fields 1963-1967, by V. Timmer, B. Bradbury and G. F. Weetman.
Forestry in Action

Institute Affairs

Section Affairs

Provincial Professional News

Outer Bark

Pag

Pag
43
46
48
52

43 Letters

C.I.F. Awards

Obituaries

Advertisers Index

Membership 